Notification List

Correspondence

Jean Euzéby

email address can be found at

www.bacterio.net

\section{Notification that new names and new combinations have appeared in volume 62 , part 4 , of the IJSEM}

This listing of names published in a previous issue of the IJSEM is provided as a service to bacteriology to assist in the recognition of new names and new combinations. This procedure was proposed by the Judicial Commission [Minute 11(ii), Int J Syst Bacterio/ 41 (1991), p. 185]. The names given herein are listed according to the Rules of priority (i.e. page number and order of valid publication of names in the original articles). Taxonomic opinions included in this List (i.e. the creation of synonyms or the emendation of circumscriptions) cannot be considered as validly published nor, in any other way, approved by the International Committee on Systematics of Prokaryotes and its Judicial Commission.

\begin{tabular}{|c|c|c|}
\hline Name/author(s): & Proposed as: & Page no. \\
\hline Thermosyntropha tengcongensis Zhang et al. 2012 & sp. nov. & 762 \\
\hline Sinomonas Zhou et al. 2009 emend. Zhou et al. 2012 & emend. ${ }^{*} \dagger$ & 767 \\
\hline Sinomonas soli Zhou et al. 2012 & sp. nov. ${ }^{*}$ & 767 \\
\hline Myroides Vancanneyt et al. 1996 emend. Yan et al. 2012 & emend. $\dagger$ & 773 \\
\hline Myroides profundi Zhang et al. 2009 emend. Yan et al. 2012 & emend. $\dagger$ & 773 \\
\hline Myroides marinus Cho et al. 2011 emend. Yan et al. 2012 & emend. $\dagger$ & 773 \\
\hline Myroides phaeus Yan et al. 2012 & sp. nov. & 773 \\
\hline Blautia stercoris Park et al. 2012 & sp. nov. & 778 \\
\hline Streptomyces panacagri Cui et al. 2012 & sp. nov. & 783 \\
\hline Pseudoclavibacter caeni Srinivasan et al. 2012 & sp. nov. & 789 \\
\hline Corynebacterium deserti Zhou et al. 2012 & sp. nov. & 793 \\
\hline Herbiconiux Behrendt et al. 2011 emend. Hamada et al. 2012 & emend. $\dagger$ & 798 \\
\hline Herbiconiux flava Hamada et al. 2012 & sp. nov. & 798 \\
\hline Sphingobium jiangsuense Zhang et al. 2012 & sp. nov. & 803 \\
\hline Flavobacterium yonginense Joung et al. 2012 & sp. nov. & 809 \\
\hline Flavobacterium myungsuense Joung et al. 2012 & sp. nov. & 809 \\
\hline Bacillus iranensis Bagheri et al. 2012 & sp. nov. & 814 \\
\hline Cohnella arctica Jiang et al. 2012 & sp. nov. & 820 \\
\hline Microbacterium yannicii Karojet et al. 2012 & sp. nov. & 825 \\
\hline Chryseobacterium vietnamense $\mathrm{Li}$ and Zhu 2012 & sp. nov. & 830 \\
\hline Anaerobaculum Rees et al. 1997 emend. Maune and Tanner 2012 & emend. $\dagger$ & 836 \\
\hline Anaerobaculum hydrogeniformans Maune and Tanner 2012 & sp. nov. & 836 \\
\hline Marivita hallyeonensis Yoon et al. 2012 & sp. nov. $\ddagger$ & 842 \\
\hline Marivita Hwang et al. 2009 emend. Yoon et al. 2012 & emend. $\dagger \ddagger$ & 843 \\
\hline Tropicibacter multivorans Lucena et al. 2012 & sp. nov. & 847 \\
\hline Brevibacillus aydinogluensis Inan et al. 2012 & sp. nov. & 853 \\
\hline Streptomyces gramineus Lee et al. 2012 & sp. nov. & 858 \\
\hline Lactobacillus xiangfangensis $\mathrm{Gu}$ et al. 2012 & sp. nov. & 862 \\
\hline Streptomyces nanhaiensis Tian et al. 2012 & sp. nov. & 866 \\
\hline Aquimarina agarilytica Lin et al. 2012 & sp. nov. & 872 \\
\hline Pseudomonas baetica López et al. 2012 & sp. nov. & 879 \\
\hline Planococcus plakortidis Kaur et al. 2012 & sp. nov. & 887 \\
\hline Carboxydocella manganica Slobodkina et al. 2012 & sp. nov. & 892 \\
\hline Rhizobium skierniewicense Puławska et al. 2012 & sp. nov. & 897 \\
\hline Rhodococcus artemisiae Zhao et al. 2012 & sp. nov. & 903 \\
\hline Simiduia areninigrae Kim et al. 2012 & sp. nov. & 909 \\
\hline
\end{tabular}


cont.

\begin{tabular}{|c|c|c|}
\hline Name/author(s): & Proposed as: & Page no. \\
\hline Aureitalea Park et al. 2012 & gen. nov. & 915 \\
\hline Aureitalea marina Park et al. 2012 & sp. nov. & 915 \\
\hline Ruegeria halocynthiae Kim et al. 2012 & sp. nov. & 928 \\
\hline Roseovarius halocynthiae Kim et al. 2012 & sp. nov. & 934 \\
\hline Flammeovirga pacifica Xu et al. 2012 & sp. nov. & 940 \\
\hline Bacillus daliensis Zhai et al. 2012 & sp. nov. & 952 \\
\hline Salinactinospora Chang et al. 2012 & gen. nov. & 958 \\
\hline Salinactinospora qingdaonensis Chang et al. 2012 & sp. nov. & 958 \\
\hline Actinoplanes abujensis Sazak et al. 2012 & sp. nov. & 963 \\
\hline Streptomyces staurosporininus Kim et al. 2012 & sp. nov. & 969 \\
\hline Isoptericola nanjingensis Huang et al. 2012 & sp. nov. & 975 \\
\hline
\end{tabular}

${ }^{*}$ In the April 2012 issue of the IJSEM, Zhou et al. propose the two following new combinations: Sinomonas echigonensis (Ding et al. 2009) Zhou et al. 2012 (basonym Arthrobacter echigonensis Ding et al. 2009) and Sinomonas albida (Ding et al. 2009) Zhou et al. 2012 (basonym Arthrobacter albidus Ding et al. 2009). The type strains are cited as $\mathrm{LC} 10^{\mathrm{T}}\left(=\mathrm{IAM} 15385^{\mathrm{T}}=\mathrm{CCTCC} \mathrm{AB} 206017^{\mathrm{T}}\right)$ and $\mathrm{LC} 13^{\mathrm{T}}\left(=\mathrm{IAM} 15386^{\mathrm{T}}=\mathrm{CCTCC} \mathrm{AB}\right.$ $206018^{\mathrm{T}}$ ), respectively. The IAM numbers cited in the paper by Zhou et al. 2012 are associated with a collection that had ceased to operate prior to publication of the paper. The JCM has accessioned many of the IAM strains. IAM 15385 was accessioned as JCM 21829 and IAM 15386 was accessioned as JCM 21830. However, neither strains IAM 15385 and IAM 15386 nor strains JCM 21829 and JCM 21830 were available at the time of publication. So, according to Rule 30(3b), the names Sinomonas echigonensis and Sinomonas albida are not validly published, and they are not cited in this Notification List.

$\dagger$ Taxonomic opinion.

¥In the April 2012 issue of the IJSEM, Yoon et al. 2012 propose the new combination Marivita byunsanensis (Yoon et al. 2010) Yoon et al. 2012 (basonym Gaetbulicola byunsanensis Yoon et al. 2010). However, the type strain is not cited in the description of the new combination ('protologue'). So, according to Rules 16,27(3) and 30(3b), the name Marivita byunsanensis is not validly published and it is not cited in this Notification List.

§Category not covered by the Rules of the Bacteriological Code (1990 Revision). 